Terbit online pada laman web jurnal : http://teknosi.fti.unand.ac.id/

Jurnal Nasional Teknologi dan Sistem Informasi

ISSN (Print) 2460-3465 | ISSN (Online) 2476-8812

Research Article

\title{
A Literature Survey on ICTD Research by IS Community
}

\author{
Luthfi Ramadani \\ Program Studi Sistem Informasi, Telkom University, Bandung, Indonesia
}

\begin{tabular}{l} 
INFORMASI ARTIKEL \\
\hline Sejarah Artikel: \\
Diterima Redaksi: 15 Juli 2017 \\
Revisi Akhir: 05 September 2017 \\
Diterbitkan Online: 10 September 2017 \\
KATA KUNCI \\
\hline ICTD \\
ICT4D \\
bibliographic study \\
systematic literature review \\
theoretical lenses \\
KORESPONDENSI \\
\hline
\end{tabular}

E-mail: luthfi@telkomuniversity.ac.id

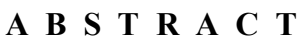

Despite a huge number of Information and Communications Technology for Development (ICTD) research so far, little is known about the landscape of published articles in Information Systems (IS) literature. This paper systematically reviews extant ICTD research published in the IS field from 1980-2016. The author systematically analyzed 192 articles published in A* and A-rank IS journals and explored which theoretical lenses, contexts, units of analysis, types of technology, and research methods dominate extant research in the field. As such, this present work provides a unique snapshot of the current research landscape that can help future ICTD field progress.

\section{INTRODUCTION}

As a mature and interdisciplinary field, ICTD has invited participation from numerous disciplines for several decades such as development studies, medicine, environmental engineering, computer science, social science, decision science, etc. Motivated by the constellation of theories circling around ICTD by Heeks [1] and Wowak et al. [2], in which informatics and development studies are two essential fields building ICTD studies, the author believes that IS represents a bridging discipline between these fields.

Most of the ICTD literature reviews typically examined specialized journals as their main source pool, notably Information Technology for Development (ITD), Information Technologies and International Development (ITID), and Electronic Journal of Information Systems in Developing Countries (IJISDC). For example, Gomez [3] conducted a bibliometric study (including the level of examination, research paradigm, method, and demography) of ICTD research published in specialized ICTD journals and conferences. Several other

https://doi.org/10.25077/ TEKNOSI.v3i2.2017.255-268 reviews generally concentrated on examining specific topic such as ICT Barriers and Success Factors [4], ICTD project outcomes [5], healthcare informatics [6], [7], e-government adoption and implementation [8], [9], Human Computer Interaction [10], and even gender issue [11]. In addition, previous reviews also have an issue with methodological limitation, which is generally found in expert review articles [12]-[14]. While some articles have already used IS journals, [15]-[17], these studies limited their source pool into only subjectively popular IS journals $(9,11$, and 8 journals respectively).

The issue of publishing ICTD research in top journals has been debated in years. The authors argue that this is difficult in nature, forcing them to publish in unranked journals or develop their own journals [18]. In her review, Naudé [18] shows that most of the specialized ICTD journals are not listed in a notable citation database, or with low rank. She argues that the low novelty of theory, low impact, and low acceptance from the original player (e.g. African researcher), are main problems of why ICTD is difficult to reach top journals. In this case, even when ICTD researchers have tried to address theoretical implications, the universality of what emerged from contextuality are frequently questioned by the reviewers in top IS publication [19], mainly due

Attribution-NonCommercial 4.0 International. Some rights reserved 
to the impossibility of replication of the practices [20]. While various arguments arose in publishing ICTD studies, one central questions might help in this case; what sort of research that successfully published in top IS journals.

This study aims to review ICTD studies published in top IS journals and summarize the theories, context, topic, and research design, then identify research trend and gaps based on the findings. The author combined literature review methodology suggested by Vom Brocke et al. [21] and Webster \& Watson [22] which consists of three stages; defining goal and scope of review, literature search-filter-analysis, and synthesizing the results. By using systematic literature review, the author aims to maximize the extensive coverage of the field and repeatability of the searching-filtering process. While the quality of reviews arguably is not dependent on the method, the well-documented and structured approach in the searching process enable the readers to assess the validity of the reviews [21]. This aspect of the review process is crucial since ICTD is an interdisciplinary field with no clear cross-sections boundary and where the foundation exactly placed [18]. Moreover, conducting a literature review on a mature field provides an accumulative understanding of the body of research as well as substantive direction on extending the field [22]. In the next section, the author describes the research method and data sample before present the analysis of the dataset. Finally, this article concludes with suggestions for future research.

\section{METHODS}

\section{$2.1 \quad$ Search strategy}

A* and A-ranked IS journals based on Excellence in Research for Australia (ERA) \& Australian Business Deans Council (ABDC) ranking were reviewed, which comprises a total of 71 journals. All versions of journal ISSN number were used when searching all articles using citation database Scopus. As for search terms, the author combined various nomenclature of ICTD in the literature (see fig.1). In order to prevent result bias, 'development' was not included as this term is interchangeable with another different topic within IS, mainly software development. Finally, the forward-backward technique was not needed since the author had determined the source pool from the beginning.

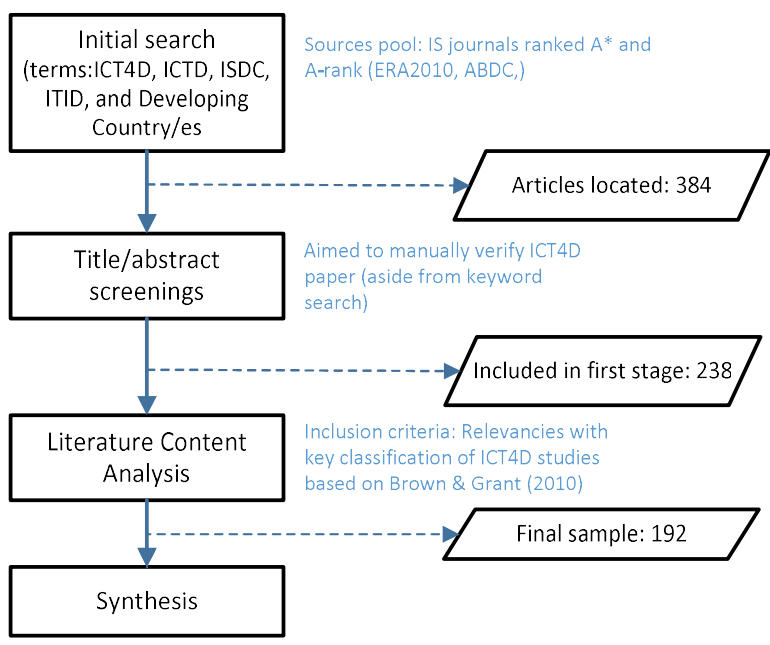

Figure 1 Literature Review Methodology

\subsection{Sample selection and data analysis}

The search process was conducted at the end of 2016. In the beginning, 384 articles were found. First verification was conducted by scanning the title, abstract, and keyword. When necessary, full-text reading was undertaken in this first stage. A total of 146 articles were removed in first selection due to irrelevancies with ICTD topic or different focus of the paper. In the next stage, content analysis was conducted to determine the suitability of the articles. ICTD research classification by Brown \& Grant [17] was used as the foundation of inclusion/exclusion justification of the articles During this step, 46 articles were removed.

As a final sample, 192 articles are analysed in this study, of which 171 are research articles, 4 are editorial, 1 research note, and 16 review articles. The author intentionally did not use the document type as exclusion criteria, but purely on the relevancies of the content. This step also validates the categorization of document type of Scopus system, as the author found several review article which share similar identities with research articles such as articles by Jaruwachirathanakul \& Fink [23], Boateng et al. [24], Wresch \& Fraser [25], Tan \& Ludwig [26], or article-in-press by Rana et al. [27], de Brito et al. [28]. Next, the author identifies seven key points in final samples; theoretical lens, research approach, research method, context/sector of examination, research topic or unit of analysis, the level of analysis, and the technology discussed in the articles.

The dataset (fig.2) comprises 192 articles from 34 journals. Most articles based on the journals appearance in the dataset are International Journal of Information Management (22 articles), Journal of Global Information Management (22 articles), International Journal of Medical Informatics (16 articles), Information Technology and People (16 articles), MIS Quarterly (11 articles), Communication of the ACM (11 articles), Information and Management, and Journal of Information Technology ( 9 respectively). The dataset comprises a total of 498 authors. 
Distribution of publication per year $(n=192)$

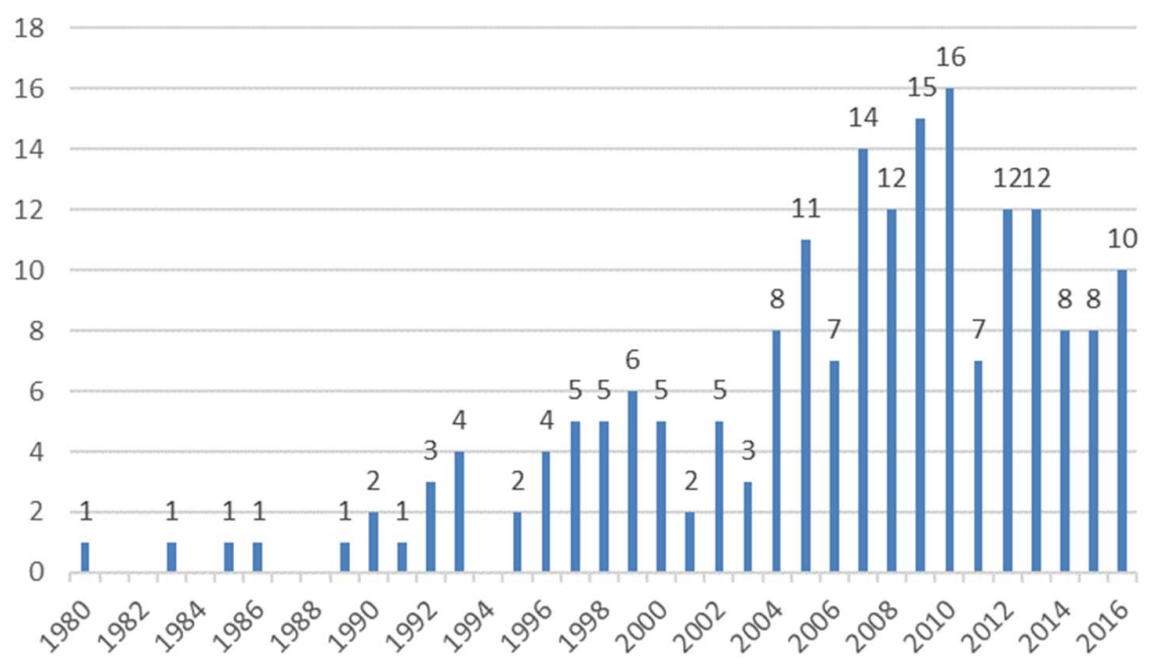

Figure 2 Distribution of articles analyzed in this review

\section{FINDINGS}

\subsection{Theories informing ICTD research}

Avgerou [13], [14] proposes two perspectives of ICTD research to understand the different purpose of theories in this field. First is the technology-transfer or top-down approach, which classify every research and practices where project initiators such as government, NGOs, and vendors try to diffuse new technology to certain groups / communities. As such, Diffusion of Innovation (DOI) and Technology Acceptance Model (TAM) are prominent theories in technology-transfer discourse [13, p. 135], [14, p. 3]. The second discourse is socially embeddedness, or bottom-up approach, where researchers prioritize their understanding of the social configuration first prior suggesting the innovation. Most of the studies categorized in this discourse use theories from social science discipline to guide context-specific action, such as complexity theory, Actor Network Theory (ANT), and institutional theory [13, p. 135], [14, p. 4].

The author identifies 66 articles that use theories to guide their ICTD research. As shown in fig.3, the result indicates that technology-transfer theories were the most popular of ICTD research in the time period. The rest of the papers either developed their own framework or used previously published models, such as Perceived eReadiness Model [26], [29], or Human-Organization-Technology fit model [30]. In most cases, the authors use broad perspective from development studies or digital divide as the background of ICTD studies [24], [31]-[33].

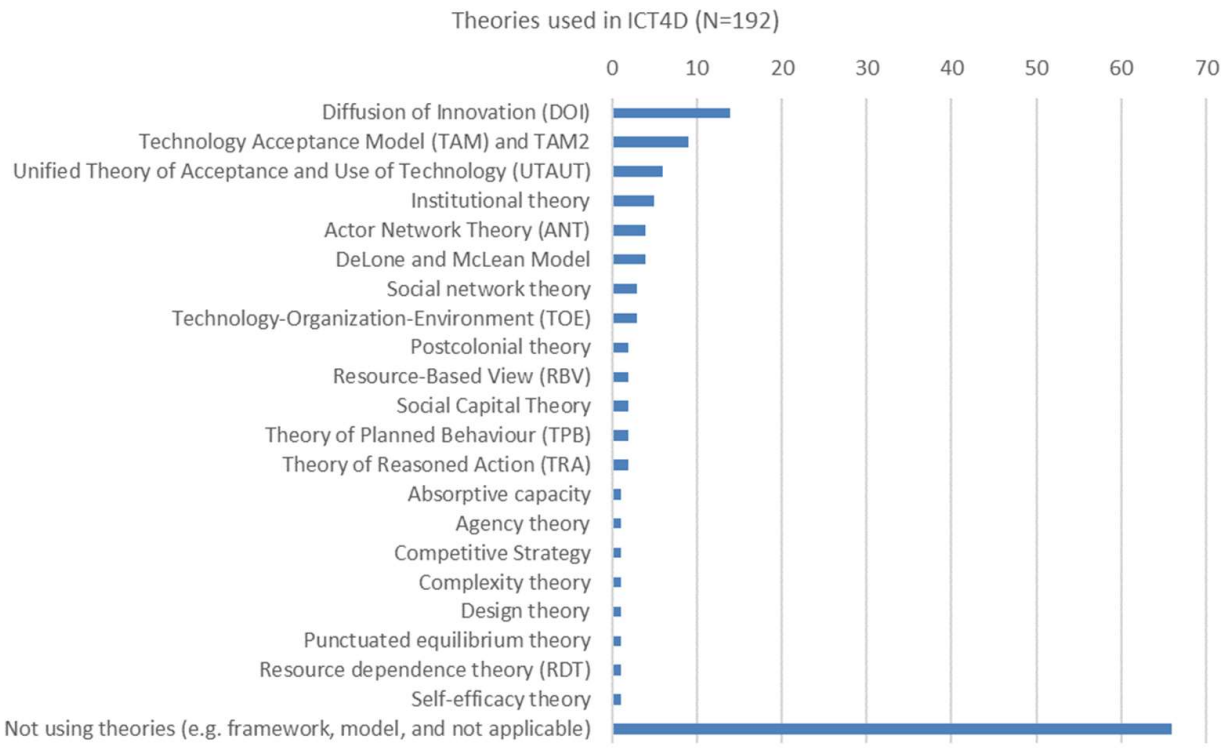

Figure 3 Distribution of theories used in dataset 


\subsection{Research methods used in ICTD research}

The qualitative approach, including qualitative case study, ethnography, critical research, and action research, appears to be the most popular approach in the dataset, followed by quantitative studies. The author group the general reviews, theoretical framework papers, research notes, and editorial articles as a conceptual approach, which is third placed. In addition, as suggested by Gomez [3], mixed methods research has invited some interests to ICTD researchers and would be growing in the future [34]-[38]. Fig. 4 illustrates the research approach analyzed in the dataset.

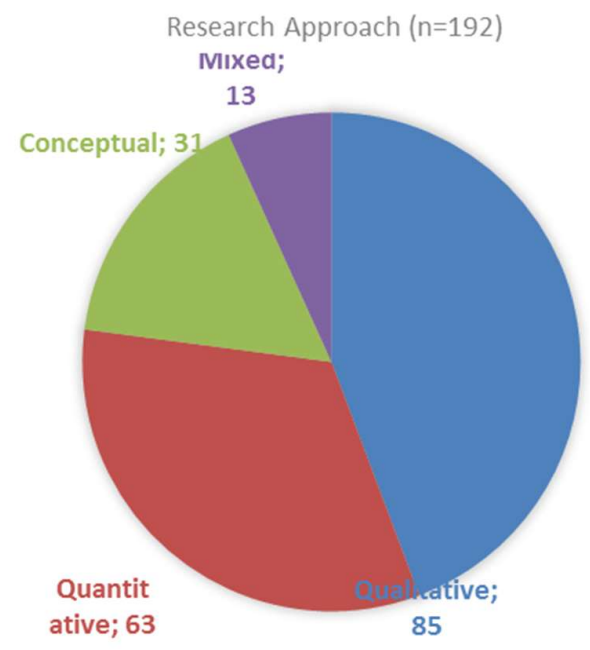

Figure 4 Research Approach

In research methods (fig. 5), the result indicates that in IS publication, the descriptive contents (e.g. describing experiences, project evaluations, best practices) are popular as same as the articles published in specialized ICTD journals [3, p. 8]. The finding also recalls Walsham \& Sahay [39] suggestions about the lack of action research and ethnography studies in this field. Finally, the author identifies the document analysis as a distinct research method [40] to distinguish them with data collection approach frequently used in research method (e.g. questionnaire, interview, focus group).

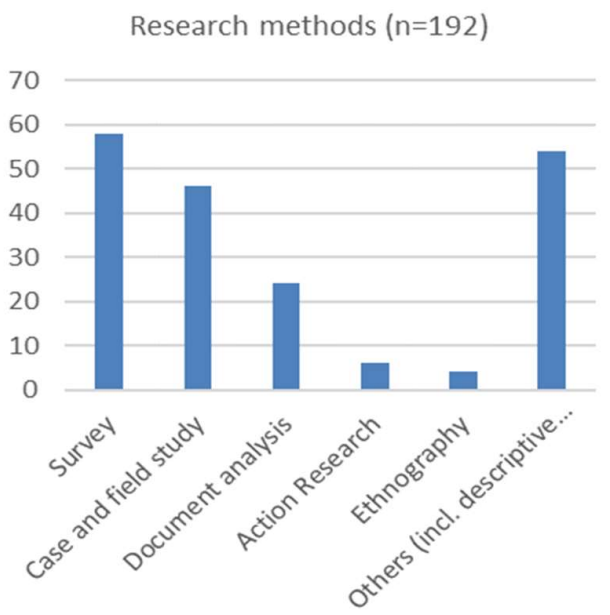

Figure 5 Research Method

\subsection{Units of analysis and contexts in ICTD research}

The overall finding shows no surprise that country-level and organization-level are the most popular focuses of studies, followed by an individual (e.g. user acceptance and behavior) and community level. However, the findings suggest that organizational-level is favored the most, whereas the previous reviews generally suggested the popularity of country-level see [3, p. 12], [41, p. 352]. The different sources between top IS journals and specialized ICTD publication might become the main reason for this discrepancy. Nevertheless, the better explanation is that in this study, the author defines the level of analysis as the object of studies and then where the primary contribution of the findings take place. It implies that even in the title, authors explicitly mention "lesson from certain country", the justification is still based on the aims of the study described in the content. For example, the author classifies the article by Uzoka \& Ndzinge [42] as organizational-level study since in that particular paper, they examined the organizational structure (managerial position) and their impact on ICT innovation, regardless the country mentioned in the title or the potential of generalizability of the findings to the country-level. Multilevel of analysis, on the other hand, which examines the interaction between levels to understand the holistic perspective of ICT implementation (e.g. examine macro-sociopolitical factor affecting local context adaptation of ICT) [14] seems to be lacking in number e.g. , [43], [44].

\section{Level of Analysis ( $\mathrm{N}=192)$}

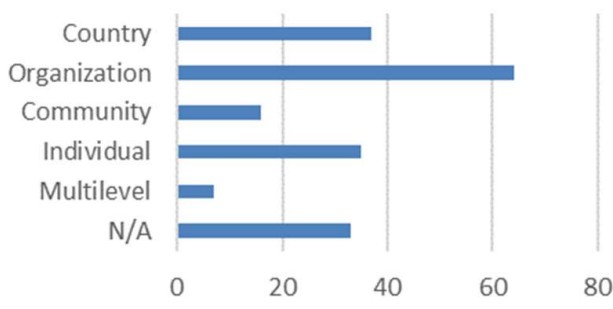

Figure 6 Unit of Analysis

On the other hand, healthcare sector appears to be the most favorable contexts, in addition to the other three (business, government, and social) mentioned in the previous reviews [3], [45]. The finding suggests a need for more research in other sectors, such as tourism and agriculture. Related articles such as a study by Adam \& Urquhart [46] who evaluated IT capacity building for tourism organization in Maldives and emphasized the role of computer and internet in enabling knowledge transfer. Another example is the study by Dey et al. [47] who evaluated Bangladesh's farmer's eagerness to use a mobile phone for their benefits but inhibited by language barriers of using English that pre-installed in the devices. 
Sector of Research ( $\mathrm{n}=192)$

$$
\begin{array}{llllllll}
0 & 5 & 10 & 15 & 20 & 25 & 30 & 35
\end{array}
$$

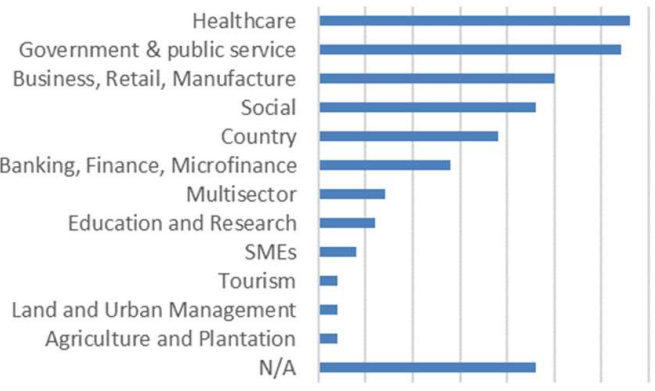

Figure 7 Research Contexts

\subsection{Research topics in ICTD research}

Relatively similar to another review on non-IS literature e.g. , [41], the author found that in IS journals, ICT adoption and ICT use/implementation are the major topics in ICTD research. ICT Impact, on the other hand, is more popular in IS publication compared other sources see [41, p. 351]. The rest of the articles discuss other topics such as ICT design (systems and software development), IS management, and specific issue on ICT infrastructure in developing countries (see fig. 8).

Topic of Articles ( $n=227$, multiple count allowed)

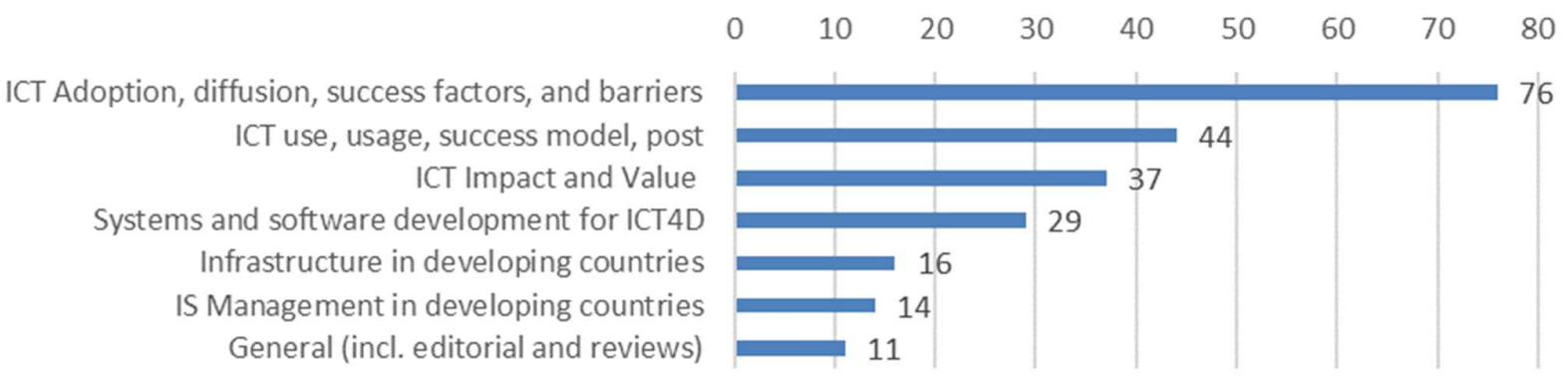

Figure 8 Research topic

Concurred with what Gomez [3] found in the specialized ICTD journals, general classification of ICT also dominates the publication during the time period. However, the distribution of the number, as illustrated in Table 1 below, shows more variety of technology examined in ICTD studies. Following Walsham \& Sahay [16] suggestion ten years ago, this field requires more in- depth studies on particular technologies examining the way they are used and adopted in the society [16, pp. 17-18]. This result also suggests that the main issue of ICT in developing countries is no longer the availability of infrastructure, but the pervasiveness of ICT in a variety of life aspects.

Table 1 Technology in ICTD

\begin{tabular}{lc}
\hline Technology/ICT & Count (n=192) \\
\hline $\begin{array}{l}\text { General classification of ICT (incl. computer, PC, microcomputer, } \\
\text { telephone, telecommunication infrastructure) }\end{array}$ & 24 \\
\hline Health information systems (incl. telemedicine, clinical system, mhealth) & 22 \\
\hline Internet, internet kiosk, telecentre, wireless, WLAN & 17 \\
\hline Enterprise IT (EDC, EIS, DSS, ERP) and e-business (e-proc) & 16 \\
\hline E-government & 15 \\
\hline E-commerce & 14 \\
\hline Internet and mobile banking & 11 \\
\hline Mobile technology & 6 \\
\hline Electronic Medical Record, EHR & 6 \\
\hline Geographical information systems (GIS) & 5 \\
\hline Cloud computing & 2 \\
\hline Social network & 2 \\
\hline Miscellaneous (e.g. biometric, eTourism, e-learning) & 8 \\
\hline N/A & 44 \\
\hline
\end{tabular}




\section{CONCLUSION And FUTURE RESEARCH}

This study demonstrates the distinction of ICTD research published in IS publication compared to other sources, especially specialized ICTD publication. Some aspects show similar patterns, such as research approach, research method, research sector, and examined technology. However, ICTD research published in IS publication tend to use explicit theories to guide or explain their research. In his review, Roztocki \& Weistroffer [41], who used more variety of literature, found only 8 articles out of 173 total samples $( \pm 4,6 \%)$ that use theories in their studies, which is significantly small compared to the finding in this study $( \pm 34 \%)$. Furthermore, this study also suggests the popularity of healthcare sector in IS publication and ICT Impact / Value as the general topic of examination.

\section{REFERENCES}

[1] R. Heeks, "Theorizing ICT4D Research," Information Technologies and International Development, vol. 3, no. 3, pp. 1-4, 2007.

[2] K. D. Wowak, C. M. Angst, I. Adjerid, and J. C. Guzman, "A Tutorial on Empirical ICT4D Research in Developing Countries: Processes, Challenges, and Lessons," Communication of the Association for Information Systems, vol. 38, no. Article 21, pp. 353374, 2016.

[3] R. Gomez, "The changing field of ICTD: Growth and maturation of the field, 2000-2010," Electronic Journal of Information Systems in Developing Countries, vol. 58, no. 1, pp. 1-21, 2013.

[4] A. Touray, A. Salminen, and A. Mursu, "ICT Barriers and Critical Success Factors in Developing Countries," The Electronic Journal of Information Systems in Developing Countries, vol. 56, no. 7, pp. 1-17, 2013.

[5] D. Thapa and Ø. Sæbø, "Exploring the Link between ICT and Development in the Context of Developing Countries: A Literature Review," The Electronic Journal of Information Systems in Developing Countries, vol. 64, pp. 1-15, 2014.

[6] F. Williams, S. Austin, and B. Mha, "The role of the electronic medical record (EMR) in care delivery development in developing countries: a systematic review," Informatics in Primary Care, vol. 16, pp. 139 145, 2008.

[7] E. Tomasi, L. a Facchini, and M. F. Maia, "Health information technology in primary health care in developing countries: a literature review," Bulletin of the World Health Organization, vol. 82, no. 11, pp. 867874, 2004.

[8] K. Hedström and A. Grönlund, "The quest for development: reviewing ICT4D research," GlobDev 2008: Proceedings annual workshop of the AIS, vol. Paper 24, 2008.

[9] F. Wahid, "Themes of research on eGovernment in developing countries: Current map and future roadmap," Proceedings of the Annual Hawaii International

260 Lutfhi Ramadani
Nevertheless, this study might have several limitations. Since the author used online citation database as a primary tool for searching, there might be possibilities where relevant articles are missed due to incomplete data on abstract, keywords, stored in the citation database. In addition, the author employed both deductive and inductive approach in categorizing and coding the articles, which might constitute the subjectivity of the analysis.

\section{ACKNOWLEDGEMENT}

This paper derives from the author's doctoral study. The author would like to thank Lembaga Pengelola Dana Pendidikan (LPDP) Kementerian Keuangan Republik Indonesia for the scholarship.

Conference on System Sciences, no. April 2010, pp. 1743-1752, 2013.

[10] M. Ho and T. Smyth, "Human-computer interaction for development: The past, present, and future," Information Technologies \& International Development, vol. 5, no. 4, pp. 1-18, 2009.

[11] H. Gillard, D. Howcroft, N. Mitev, and H. Richardson, "'Missing women': Gender, ICTs, and the shaping of the global economy," Information Technology for Development, vol. 14, no. 4, pp. 262-279, 2008.

[12] R. Heeks, "Information systems and developing countries: failure, success, and local improvisations," The Information Society, vol. 18, no. 2, pp. 101-112, 2002.

[13] C. Avgerou, "Information systems in developing countries: A critical research review," Journal of Information Technology, vol. 23, no. 3, pp. 133-146, 2008.

[14] C. Avgerou, "Discourses on ICT and Development," Information Technologies \& International Development, vol. 6, no. 3, pp. 1-18, 2010.

[15] S. Sahay and G. Walsham, "Information technology in developing countries: A need for theory building," Information Technology for Development, vol. 6, no. 34, pp. 111-124, 1995.

[16] G. Walsham and S. Sahay, "Research on information systems in developing countries: current landscape and future prospects," Information Technology for Development, vol. 12, no. 1, pp. 7-24, 2006.

[17] A. Brown and G. Grant, "Highlighting the Duality of the ICT and Development Research Agenda," Information Technology for Development, vol. 16, no. 2, pp. 96-111, 2010.

[18] F. Naudé, "Electronic Journal of Information Systems in Developing Countries (2000 - 2013): a Bibliometric Study," The Electronic Journal of Information Systems in Developing Countries, vol. 72, no. 3, pp. 1-23, 2016.

[19] P. J. Ågerfalk, "Insufficient theoretical contribution: A conclusive rationale for rejection?," European Journal of Information Systems, vol. 23, pp. 593-599, 2014.

[20] F. K. Andoh-baidoo, "Organizational Information and Communication Technologies for Development," Information Technology for Development, vol. 22, no. 2, pp. 193-204, 2016.

https://doi.org/10.25077/ TEKNOSI.v3i2.2017.255-268 
[21] J. von Brocke, A. Simons, B. Niehaves, K. Riemer, R. Plattfaut, and A. Cleven, "Reconstructing the Giant: On the Importance of Rigour in Documenting the Literature Search Process," in 17th European Conference on Information Systems, 2009, vol. 9, pp. 2206-2217.

[22] J. Webster and R. T. Watson, "Analyzing the Past to Prepare for the Future: Writing A Literature Review," MIS Quarterly, vol. 26, no. 2, pp. 13-23, 2002.

[23] B. Jaruwachirathanakul and D. Fink, "Internet banking adoption strategies for a developing country: the case of Thailand," Internet Research, vol. 15, pp. 295-311, 2005.

[24] R. Boateng, R. Heeks, A. Molla, and R. Hinson, Ecommerce and socio-economic development: conceptualizing the link, vol. 18, no. 5. 2008.

[25] W. Wresch and S. Fraser, "Managerial Strategies Used to Overcome Technological Hurdles: A Review of ECommerce Efforts Used by Innovative Caribbean Managers," Journal of Global Information Management, vol. 14, no. 3, pp. 1-16, 2006.

[26] J. Tan and S. Ludwig, "Regional Adoption of Businessto-Business Electronic Commerce in China," International Journal of Electronic Commerce, vol. 20, no. 3, pp. 408-439, 2016.

[27] N. P. Rana, Y. K. Dwivedi, B. Lal, M. D. Williams, and M. Clement, "Citizens' adoption of an electronic government system: towards a unified view," Information Systems Frontiers, pp. 1-20, 2015.

[28] S. R. de Brito, A. do Socorro da Silva, E. C. da Mata, N. L. Vijaykumar, C. A. J. da Rocha, M. de Abreu Monteiro, J. C. W. A. Costa, and C. R. L. Francês, "An approach to evaluate large-scale ICT training interventions," Information Systems Frontiers, 2016.

[29] J. Tan, K. Tyler, and A. Manica, "Business-to-business adoption of eCommerce in China," Information and Management, vol. 44, no. 3, pp. 332-351, 2007.

[30] J. W. Lian, D. C. Yen, and Y. T. Wang, “An exploratory study to understand the critical factors affecting the decision to adopt cloud computing in Taiwan hospital," International Journal of Information Management, vol. 34, no. 1, pp. 28-36, 2014.

[31] D. Splettstoesser, "Electronic Decision-Making for Developing Countries," Group Decision and Negotiation, vol. 7, no. 5, pp. 417-433, 1998.

[32] S. Madon, "The Internet and socio- economic development: exploring the interaction," Information Technology \& People, vol. 13, no. 2, pp. 85-101, 2000.

[33] A. Prakash and R. De', "Importance of development context in ICT4D projects," Information Technology \& People, vol. 20, no. 3, pp. 262-281, 2007.

[34] A. Z. Klein, E. Gomes da Costa, L. M. Vieira, and R. Teixeira, "The Use of Mobile Technology in Management and Risk Control in the Supply Chain," Journal of Global Information Management, vol. 22, no. 1, pp. 14-33, 2014.

[35] S. F. Noormohammad, B. W. Mamlin, P. G. Biondich,
B. McKown, S. N. Kimaiyo, and M. C. Were, "Changing course to make clinical decision support work in an HIV clinic in Kenya," International Journal of Medical Informatics, vol. 79, no. 3, pp. 204-210, 2010.

[36] S. K. Lau, G. K. Winley, N. K. Y. Leung, N. Tsang, and S. Y. Lau, "An Exploratory Study of Expectation in IT Skills in a Developing Nation:," Journal of Global Information Management, vol. 24, no. 1, pp. 1-13, 2016.

[37] W. Tian, D. Vogel, J. A. Ma, and J. B. Gu, "ISSupported Managerial Control for China's Research Community: An Agency Theory Perspective," Journal of Global Information Management, vol. 18, no. 4, pp. 53-81, 2010.

[38] R. Gomez and E. Gould, “The 'cool factor' of public access to ICT," Information Technology \& People, vol. 23, no. 3, pp. 247-264, 2010.

[39] G. Walsham, D. Robey, and S. Sahay, "Foreword: Special Issue on Information Systems in Developing Countries," MIS Quarterly, vol. 31, no. 2, pp. 317-326, 2007.

[40] G. A. Bowen, "Document analysis as a qualitative research method," Qualitative Research Journal, vol. 9, no. 2, pp. 27-40, 2009.

[41] N. Roztocki and H. R. Weistroffer, "Information and Communication Technology in Transition Economies: An Assessment of Research Trends," Information Technology for Development, vol. 21, no. February, pp. 330-364, 2015.

[42] F. M. E. Uzoka and T. Ndzinge, "Empirical analysis of biometric technology adoption and acceptance in Botswana," Journal of Systems and Software, vol. 82, no. 9, pp. 1550-1564, 2009.

[43] S. Madon, S. Sahay, and R. Sudan, "E-Government Policy and Health Information Systems Implementation in Andhra Pradesh, India: Need for Articulation of Linkages Between the Macro and the Micro," The Information Society, vol. 23, no. 5, pp. 327-344, 2007.

[44] C. I. C. Lin, F.-Y. Kuo, and M. D. Myers, "Extending ICT4D Studies: The Value of Critical Research," MIS Quarterly, vol. 39, no. 3, pp. 697-712, 2015.

[45] R. Patra, J. Pal, and S. Nedevschi, "ICTD State of the Union: Where have we reached and where are we headed," in ICTD'09 Proceedings of the 3rd international conference on Information and communication technologies, 2009, pp. 357-366.

[46] M. S. Adam and C. Urquhart, "No man is an island: Social and human capital in IT capacity building in the Maldives," Information and Organization, vol. 19, no. 1, pp. 1-21, 2009.

[47] B. Dey, D. Newman, and R. Prendergast, "Analysing appropriation and usability in social and occupational lives," Information Technology \& People, vol. 24, no. 1, pp. 46-63, 2011.

\section{APPENDIX - REFERENCES of DATASET}

\begin{tabular}{|ll|}
\hline [1] & $\begin{array}{l}\text { A. G.-O. Yeh, "The development and applications of geographic information systems for urban and regional planning in the developing } \\
\text { countries," International Journal of Geographical Information Systems, vol. 5, no. 1, pp. 5-27, 1991. }\end{array}$ \\
\hline [2] & $\begin{array}{l}\text { L. Kapiriri and S. J. Bondy, "Health practitioners' and health planners' information needs and seeking behavior for decision making in } \\
\text { Uganda," International Journal of Medical Informatics, vol. 75, no. 10-11, pp. 714-721, 2006. }\end{array}$ \\
\hline [3] & $\begin{array}{l}\text { E. E. Grandon and P. P. J. Mykytyn, "Theory-based Instrumentation to Measure the Intention to Use Electronic Commerce in Small and } \\
\text { Medium Sized Businesses," Journal of Computer Information Systems, vol. 44, no. 3, pp. 44-57, 2004. }\end{array}$ \\
\hline
\end{tabular}


[4] S. Sahay, M. Aanestad, and E. Monteiro, "Configurable Politics and Asymmetric Integration : Health e-Infrastructures in India," Journal of the Association for Information Systems, vol. 10, no. May 2009, pp. 399-414, 2009.

[5] D. Li, W. W. Huang, J. Luftman, and W. Sha, "Key Issues in Information Systems Management: An Empirical Investigation from a Developing Country's Perspective," Journal of Global Information Management, vol. 18, no. 4, pp. 19-35, 2010.

[6] S. W. Jimba and M. I. Atinmo, "The influence of information technology access on agricultural research in Nigeria," Internet Research, vol. 10, no. 1, pp. 63-71, 2000.

[7] F. H. Chandio, Z. Irani, M. S. Abbasi, and H. A. Nizamani, "Acceptance of online banking information systems: an empirical case in a developing economy," Behaviour \& Information Technology, vol. 32, no. 7, pp. 668-680, 2013.

[8] L. G. Pee, A. Kankanhalli, and V. C. Y. O. Show, "Bridging the digital divide: Use of public internet kiosks in Mauritius," Journal of Global Information Management, vol. 18, no. 1, pp. 1-14, 2010.

[9] F. Niederman, H. Alhorr, Y.-H. Park, and C. Tolmie, "Global information management research: What have we learned in the past decade?," Journal of Global Information Management, vol. 20, no. 1, pp. 18-56, 2012.

[10] D. Gefen, G. M. Rose, M. Warkentin, and P. a. Pavlou, "Cultural Diversity and Trust in IT Adoption," Journal of Global Information Management, vol. 13, no. 1, pp. 54-78, 2005.

[11] B. Jaruwachirathanakul and D. Fink, "Internet banking adoption strategies for a developing country: the case of Thailand," Internet Research, vol. 15, pp. 295-311, 2005.

[12] Y. N. Chen, H. M. Chen, W. Huang, and R. K. H. Ching, "E-government strategies in developed and developing countries: An implementation framework and case study," Journal of Global Information Management, vol. 14, no. 1, pp. 23-46, 2006.

[13] M. Cleverley, "How ICT advances might help developing nations," Communications of the ACM, vol. 52, no. 9, pp. 30-32, 2009.

[14] R. W. Blanning, T. X. Bui, and M. Tan, "National information infrastructure in Pacific Asia," Decision Support Systems, vol. 21, no. 3, pp. 215-227, 1997.

[15] R. Gholami, D. A. Higón, P. Hanafizadeh, and A. Emrouznejad, "Is ICT the Key to Development?," Journal of Global Information Management, vol. 18, no. 1, pp. 66-83, 2010.

[16] G. Sadowsky, "Network connectivity for developing countries," Communications of the ACM - Special issue on internetworking, vol. 36, no. 8, pp. 42-47, 1993.

[17] S. . De Boer and M. . Walbeek, "Information technology in developing countries: a study to guide policy formulation," International Journal of Information Management, vol. 19, no. 3, pp. 207-218, 1999.

[18] B. M. Rodriguez and J. M. Viedma Martí, "The region's intellectual capital benchmarking system: Enabling economic growth through evaluation,” Journal of Knowledge Management, vol. 10, no. 5, pp. 41-54, 2006.

[19] W. Wresch and S. Fraser, "Persistent Barriers to E-commerce in Developing Countries: A Longitudinal Study of Efforts by Caribbean Companies," Journal of Global Information Management, vol. 19, no. 3, pp. 30-44, 2011.

[20] Y. Li, Y. Duan, Z. Fu, and P. Alford, "An empirical study on behavioural intention to reuse e-learning systems in rural China," British Journal of Educational Technology, vol. 43, no. 6, pp. 933-948, 2012.

[21] I. H. Witten, M. Loots, M. E. Trujillo, and D. Bainbridge, "The Promise of Digital Libraries in Developing Countries," Communications of The ACM, vol. 44, no. 5, pp. 82-85, 2001.

[22] V. W. Mbarika, T. A. Byrd, and J. Raymond, "Growth of Teledensity in Least Developed Countries: Need for a Mitigated Euphoria," Journal of Global Information Management, vol. 10, no. 2, pp. 14-27, 2002.

[23] B. Zarei and A. Ghapanchi, "Guidelines for government-to-government initiative architecture in developing countries," International Journal of Information Management, vol. 28, no. 4, pp. 277-284, 2008.

[24] F. Williams and S. A. Boren, "The role of electronic medical record in care delivery in developing countries," International Journal of Information Management, vol. 28, no. 6, pp. 503-507, 2008.

[25] T. S. Parikh, "Engineering rural development," Communications of the ACM, vol. 52, no. 1, pp. 54-63, 2009.

[26] E. W. Baker, S. Al-Gahtani, and G. S. Hubona, "Cultural Impacts on Acceptance and Adoption of Information Technology in a Developing Country,” Journal of Global Information Management, vol. 18, no. 3, p. 35, 2010.

[27] D. Arnott, W. Jirachiefpattana, and P. O'Donnell, "Executive information systems development in an emerging economy," Decision Support Systems, vol. 42, no. 4, pp. 2078-2084, 2007.

[28] Z. Ping and D. J. Grimshaw, "A comparative study of the application of IT in China and the West: Culture and the stages of growth model," International Journal of Information Management, vol. 12, no. 4, pp. 287-293, 1992.

[29] P. Malhotra and B. Singh, "An analysis of internet banking offerings and its determinants in India," Internet Research, vol. 20, no. 1, pp. 87-106, 2010.

[30] P. Malhotra and B. Singh, "Determinants of Internet banking adoption by banks in India," Internet Research, vol. 17, no. 3, pp. 323-339, 2007.

[31] R. Jayasuriya, "Managing information systems for health services in a developing country: A case study using a contextualist framework," International Journal of Information Management, vol. 19, no. 5, pp. 335-349, 1999.

[32] C. U. Ngini, S. M. Furnell, and B. V Ghita, “Assessing the global accessibility of the Internet," Internet Research, vol. 12, no. 4, pp. 329$338,2002$.

[33] E. Shih, K. L. Kraemer, and J. Dedrick, "ICT Diffusion in Developing Countries," Communications of the ACM, vol. 51, no. 2, pp. 4348,2008 
[34] O. S. Adewale, “An internet-based telemedicine system in Nigeria," International Journal of Information Management, vol. 24, no. 3, pp. 221-234, 2004.

[35] M. Sambasivan, G. P. Wemyss, and R. C. Rose, "User acceptance of a G2B system: a case of electronic procurement system in Malaysia," Internet Research, vol. 20, no. 2, pp. 169-187, 2010.

[36] M. B. Dias and E. Brewer, "How computer science serves the developing world," Communications of the ACM, vol. 52, no. 6, pp. 7480, 2009.

[37] a. H. Abdul-Gader, "Information systems strategies for multinational companies in Arab Gulf countries," International Journal of Information Management, vol. 17, no. 1, pp. 3-12, 1997.

[38] D. A. Mirchandani, J. H. Johnson, and K. Joshi, "Perspectives of citizens towards e-government in Thailand and Indonesia: A multigroup analysis," Information Systems Frontiers, vol. 10, no. 4, pp. 483-497, 2008.

[39] M. M. M. A. Riffai, K. Grant, and D. Edgar, "Big TAM in Oman: Exploring the promise of on-line banking, its adoption by customers and the challenges of banking in Oman," International Journal of Information Management, vol. 32, no. 3, pp. 239-250, 2012.

[40] Z. Meng and S. Y. T. Lee, "The value of IT to firms in a developing country in the catch-up process: An empirical comparison of China and the United States," Decision Support Systems, vol. 43, no. 3, pp. 737-745, 2007.

[41] W. T. Lin, "The business value of information technology as measured by technical efficiency: Evidence from country-level data," Decision Support Systems, vol. 46, no. 4, pp. 865-874, 2009.

[42] C. Pimmer, S. Linxen, and U. Gröhbiel, "Facebook as a learning tool? A case study on the appropriation of social network sites from mobile phones in developing countries," British Journal of Educational Technology, vol. 43, no. 5, pp. 726-738, 2012.

[43] B. Narteh, "Knowledge transfer in developed-developing country interfirm collaborations: a conceptual framework," Journal of Knowledge Management, vol. 12, no. 1, pp. 78-91, 2008.

[44] W. William, "Initial e-commerce efforts in nine least developed countries : A Review of National Infrastructure, Business Approaches and Product Selection," Journal of Global Information Management, vol. 2, no. 11, pp. 67-78, 2003.

[45] R. B. Heeks, "Software Strategies in Developing Countries," Communications of the ACM, vol. 42, no. 6, pp. 15-17, 1999.

[46] I. Elbeltagi and N. Mcbride, "Evaluating the Factors Affecting DSS Usage by Senior Managers in Local Authorities in Egypt," Journal of Global Information Management, vol. 13, no. 2, pp. 42-65, 2005.

[47] C. Ranganathan and G. Kannabiran, "Effective management of information systems function: An exploratory study of Indian organizations," International Journal of Information Management, vol. 24, no. 3, pp. 247-266, 2004.

[48] J. W. Lian, D. C. Yen, and Y. T. Wang, "An exploratory study to understand the critical factors affecting the decision to adopt cloud computing in Taiwan hospital," International Journal of Information Management, vol. 34, no. 1, pp. 28-36, 2014.

[49] J. X. Ma, D. Buhalis, and H. Song, "ICTs and Internet adoption in China's tourism industry," International Journal of Information Management, vol. 23, no. 6, pp. 451-467, 2003.

[50] T. Bui, S. Cho, S. Sankaran, and M. Sovereign, "A framework for designing a global information network for multinational humaniratian assistance/ disaster relief," Information Systems Frontiers, vol. 4, no. 1, pp. 427-442, 2000.

[51] B. Petrazzini and M. Kibati, "The Internet in Developing Countries," Communications of the ACM, vol. 42, no. 6, pp. 31-36, 1999.

[52] K. L. Kraemer, J. Dedrick, and P. Sharma, "One Laptop per Child: Vision vs Reality," Communications of The ACM, vol. 52, no. 6, pp. 66-73, 2009 .

[53] S. Sakthivel, "Managing risk in offshore systems development," Communications of the ACM, vol. 50, no. 4, pp. 69-75, 2007.

[54] N. Park, R. Roman, S. Lee, and J. E. Chung, "User acceptance of a digital library system in developing countries: An application of the Technology Acceptance Model," International Journal of Information Management, vol. 29, no. 3, pp. 196-209, 2009.

[55] M. Anandarajan, M. Igbaria, and U. P. Anakwe, "IT acceptance in a less-developed country: A motivational factor perspective," International Journal of Information Management, vol. 22, no. 1, pp. 47-65, 2002.

[56] W. Wresch and S. Fraser, "Managerial Strategies Used to Overcome Technological Hurdles: A Review of E-Commerce Efforts Used by Innovative Caribbean Managers," Journal of Global Information Management, vol. 14, no. 3, pp. 1-16, 2006.

[57] A. Imran and S. Gregor, "Uncovering the Hidden Issues in E-Government Adoption in a Least Developed Country: The Case of Bangladesh," Journal of Global Information Management, vol. 18, no. 2, pp. 30-56, 2010.

[58] B. Bowonder, T. Miyqake, and T. M. Singh, "Emerging trends in information technology: Implications for developing countries," International Journal of Information Management, vol. 13, no. 3, pp. 183-204, 1993.

[59] M. Kifle, V. W. A. Mbarika, and P. Datta, "Interplay of cost and adoption of tele-medicine in Sub-Saharan Africa: The case of telecardiology in Ethiopia," Information Systems Frontiers, vol. 8, no. 3, pp. 211-223, 2006.

[60] R. Boateng, R. Heeks, A. Molla, and R. Hinson, E-commerce and socio-economic development : conceptualizing the link, vol. 18 , no. 5. 2008 .

[61] V. W. Mbarika, P. N. Meso, and P. F. Musa, "A Disconnect in Stakeholders' Perceptions from Emerging Realities of Teledensity Growth in Africa's Least Developed Countries," Journal of Global Information Management, vol. 12, no. 3, pp. 1-20, 2004.

[62] S. Mutula and J. M. Wamukoya, "Public sector information management in east and southern Africa: Implications for FOI, democracy and integrity in government," International Journal of Information Management, vol. 29, no. 5, pp. 333-341, 2009.

[63] J. Barjis, G. Kolfschoten, and J. Maritz, "A sustainable and affordable support system for rural healthcare delivery,” Decision Support Systems, vol. 56, no. 1, pp. 223-233, 2013.

[64] K. Saxena and A. Aly, "Information technology support for reengineering public administration: A conceptual framework," International https://doi.org/10.25077/ TEKNOSI.v3i2.2017.255-268

Luthfi Ramadani 
Journal of Information Management, vol. 15, no. 4, pp. 271-293, 1995.

[65] A. P. N. Thapisa, "The Impact of Global information on Africa," Internet Research, vol. 6, no. 1, pp. 71-78, 1996.

[66] D. Splettstoesser, "Electronic Decision-Making for Developing Countries," Group Decision and Negotiation, vol. 7, no. 5, pp. 417-433, 1998.

[67] D. G. Dologite, R. J. Mockler, Q. Bai, and P. F. Viszhanyo, "IS Change Agents in Practice in a US-Chinese Joint Venture," Journal of Global Information Management, vol. 12, no. 4, pp. 1-22, 2004.

[68] N. P. Rana, Y. K. Dwivedi, B. Lal, M. D. Williams, and M. Clement, "Citizens' adoption of an electronic government system: towards a unified view," Information Systems Frontiers, pp. 1-20, 2015.

[69] S. Sharma, E. M. Daniel, and C. Gray, “Absorptive Capacity and ERP Implementation in Indian Medium-Sized Firms,” Journal of Global Information Management, vol. 20, no. 4, pp. 54-79, 2012.

[70] M. M. Kamal, R. Hackney, and K. Sarwar, "Investigating Factors Inhibiting e-Government Adoption in Developing Countries," Journal of Global Information Management, vol. 21, no. 4, pp. 77-102, 2013.

[71] B. P. F. Musa, V. W. Mbarika, and P. Meso, "Calling for Programmed Technology Transfer Sustainable Adoption LDC Growth," Communications of The ACM, vol. 48, no. 12, pp. 111-116, 2005.

[72] M.-T. Lu and C. Farrell, "Information systems development in developing countries: An evaluation and recommendations," International Journal of Information Management, vol. 10, no. 4, pp. 288-296, 1990.

[73] J. James, "Reconstruing the digital divide from the perspective of a large, poor, developing country," Journal of Information Technology, vol. 19, no. 3, pp. 172-177, 2004.

[74] P. Meso, P. Musa, D. Straub, and V. Mbarika, "Information infrastructure, governance, and socio-economic development in developing countries,” European Journal of Information Systems, vol. 18, pp. 52-65, 2009.

[75] P. Gao, “Counter networks in standardization: a perspective of developing countries," Information Systems Journal, vol. 17, no. 4, pp. 391-420, 2007.

[76] L. Kim and J. Utterback, "The Evolution of Organizational Structure and Technology in a Developing Country," Management Science, vol. 29, no. 10, pp. 1185-1197, 1983.

[77] R. Montealegre, "Managing information technology in modernizing 'against the odds': Lessons from an organization in a less-developed country," Information \& Management, vol. 34, no. 2, pp. 103-116, 1998.

[78] P. Datta, “A preliminary study of ecommerce adoption in developing countries,” Information Systems Journal, vol. 21, no. 1, pp. 3-32, 2011.

[79] J. James, "From origins to implications: Key aspects in the debate over the digital divide," Journal of Information Technology, vol. 22, no. 3, pp. 284-295, 2007.

[80] S. Dewan, D. Ganley, and K. L. Kraemer, "Complementarities in the diffusion of personal computers and the internet: Implications for the global digital divide,” Information Systems Research, vol. 21, no. 4, pp. 925-940, 2010.

[81] S. Madon, "Governance lessons from the experience of telecentres in Kerala," European Journal of Information Systems, no. April, pp. $401-416,2005$.

[82] M. G. Martinsons, "Relationship-based e-commerce: Theory and evidence from China," Information Systems Journal, vol. 18, no. 4, pp. 331-356, 2008.

[83] G. Miscione, “Telemedicine in the Upper Amazon: Interplay with Local Health Care Practices,” MIS Quarterly, vol. 31, no. 2, pp. 403$425,2007$.

[84] L. Silva and R. Hirschheim, "Fighting Against Windmills: Strategic Information Systems And Organizational Deep Structures,” Mis Quarterly, vol. 31, no. 2, pp. 327-354, 2007.

[85] G. Walsham, D. Robey, and S. Sahay, "Foreword: Special Issue on Information Systems in Developing Countries," MIS Quarterly, vol. 31, no. 2, pp. 317-326, 2007.

[86] J. Braa, O. Hanseth, A. Heywood, W. Mohammed, and V. Shaw, "Developing health information systems in developing countries: The flexible standards strategy," MIS Quarterly, vol. 31, no. 2, pp. 381-402, 2007.

[87] J. Tan, K. Tyler, and A. Manica, "Business-to-business adoption of eCommerce in China," Information and Management, vol. 44, no. 3, pp. 332-351, 2007

[88] S. L. Jarvenpaa and D. E. Leidner, "An Information Company In Mexico: Extending The Resource-Based View Of The Firm," Information Systems Research, vol. 9, no. 4, pp. 342-361, 1998.

[89] C. Avgerou, "Information systems in developing countries: A critical research review," Journal of Information Technology, vol. 23, no. 3, pp. 133-146, 2008.

[90] A. Molla and P. S. Licker, "ECommerce adoption in developing countries: A model and instrument," Information and Management, vol. 42, no. 6, pp. 877-899, 2005.

[91] J. Braa, E. Monteiro, and S. Sahay, "Networks of Action: Sustainable Health Information Systems Across Developing Countries," MIS Quarterly, vol. 28, no. 3, pp. 337-362, 2004.

[92] S. Dewan and K. L. Kraemer, "Information technology and productivity: Evidence from country-level data," Management Science, vol. 46, no. 4, pp. 548-556, 2000.

[93] G. Walsham and S. Sahay, "GIS for District-Level Administration in India: Problems and Opportunities,” MIS Quarterly, vol. 23, no. 1, pp. 39-66, 1999. 
[94] K. Zhu, K. L. Kraemer, and S. Xu, "The Process of Innovation Assimilation by Firms in Different Countries: A Technology Diffusion Perspective on E-Business," Management Science, vol. 52, no. 10, pp. 1557-1576, 2006.

[95] K. Zhu and K. L. Kraemer, "Post-Adoption Variations in Usage and Value of E-Business by Organizations: Cross-Country Evidence from the Retail Industry," Information Systems Research, vol. 16, no. 1, pp. 61-84, Mar. 2005.

[96] S. McCoy, "Modeling internet diffusion in developing countries," Australasian Journal of Information Systems, vol. 17, no. 2, pp. 5-22, 2012.

[97] A. Z. Klein, E. Gomes da Costa, L. M. Vieira, and R. Teixeira, "The Use of Mobile Technology in Management and Risk Control in the Supply Chain," Journal of Global Information Management, vol. 22, no. 1, pp. 14-33, 2014.

[98] L. Brooks and M. S. Alam, "Designing an information system for updating land records in Bangladesh: Action design ethnographic research (ADER)," Information Systems Frontiers, vol. 17, no. 1, pp. 79-93, 2014.

[99] M. M. Ashraf, H. Grunfeld, and A. Quazi, "Impact of ICT usage on indigenous peoples' quality of life: Evidence from an Asian developing country," Australasian Journal of Information Systems, vol. 19, pp. 1-16, 2015.

[100] S. K. Lau, G. K. Winley, N. K. Y. Leung, N. Tsang, and S. Y. Lau, "An Exploratory Study of Expectation in IT Skills in a Developing Nation:," Journal of Global Information Management, vol. 24, no. 1, pp. 1-13, 2016.

[101] S. R. de Brito, A. do Socorro da Silva, E. C. da Mata, N. L. Vijaykumar, C. A. J. da Rocha, M. de Abreu Monteiro, J. C. W. A. Costa, and C. R. L. Francês, "An approach to evaluate large-scale ICT training interventions," Information Systems Frontiers, 2016.

[102] S. S. Bisht and V. Mishra, "ICT-driven financial inclusion initiatives for urban poor in a developing economy: implications for public policy," Behaviour \& Information Technology, vol. 3001, no. July, pp. 1-16, 2016.

[103] J. S. Edralin, "Managing information systems for urban and regional planning in Asian metropolitan regions," International Journal of Information Management, vol. 6, no. 4, pp. 207-223, 1986.

[104] W. Tian, D. Vogel, J. A. Ma, and J. B. Gu, "IS-Supported Managerial Control for China's Research Community: An Agency Theory Perspective," Journal of Global Information Management, vol. 18, no. 4, pp. 53-81, 2010.

[105] E. H. Diniz, M. Jayo, M. Pozzebon, F. Lavoie, and F. H. D. S. Foguel, "ICT Helping to Scale up Microfinance," Journal of Global Information Management, vol. 22, no. 1, pp. 34-50, 2014.

[106] A. Neupane, J. Soar, and K. Vaidya, "An Empirical Evaluation of hte Potential of Public E-Procurement to Reduce Corruption," Australasian Journal of Information Systems, vol. 18, no. 2, pp. 21-44, 2014.

[107] E. J. Y. Liew, S. Vaithilingam, and M. Nair, "Facebook and socio-economic benefits in the developing world," Behaviour \& Information Technology, vol. 33, no. 4, pp. 345-360, 2014.

[108] Y. Chang, H. Kim, S. F. Wong, and M.-C. Park, “A Comparison of the Digital Divide Across Three Countries with Different Development Indices," Journal of Global Information Management, vol. 23, no. 4, pp. 55-76, 2015.

[109] R. Sooryamoorthy, "Producing information: communication and collaboration in the South African scientific community," Information, Communication \& Society, vol. 4462, no. May, pp. 1-19, 2015.

[110] A. M. Aladwani, "Corruption as a source of e-Government projects failure in developing countries: A theoretical exposition," International Journal of Information Management, vol. 36, no. 1, pp. 105-112, 2016.

[111] H. M. Sabi, F. E. Uzoka, K. Langmia, and F. N. Njeh, "Conceptualizing a model for adoption of cloud computing in education," International Journal of Information Management, vol. 36, no. 2, pp. 183-191, 2016.

[112] S. Palvia; R. M. Zigli, "Models and Requirements for Using Strategic Information Systems in Developing Nations,” International Journal of Information Management, vol. 10, no. 2, pp. 117-126, 1990.

[113] A. H. Abdul-Gader, "Usage pattern and productivity impact of computer-mediated communication in a developing country: An exploratory study," International Journal of Information Management, vol. 16, no. 1, pp. 39-49, 1996.

[114] R. Mansell, "Constructing the knowledge base for knowledge-driven development," Journal of Knowledge Management, vol. 6, no. 4, pp. 317-329, 2002.

[115] P. Olla and J. Choudrie, "Mobile technology utilization for social development in developing countries: An ethnographic futures research study," Information Systems Frontiers, vol. 16, no. 3, pp. 369-382, 2014.

[116] J. Dedrick, K. L. Kraemer, and E. Shih, "Information Technology and Productivity in Developed and Developing Countries," Journal of Management Information Systems, vol. 30, no. 1, pp. 97-122, 2013.

[117] S. C. Srivastava and G. Shainesh, "Bridging the Service Divide Through Digitally Enabled Service Innovations: Evidence From Indian Healthcare Service Providers.," MIS Quarterly, vol. 39, no. 1, pp. 245-268, 2015.

[118] S. Lee, J. Y. Xiang, and J. K. Kim, "Information technology and productivity: Empirical evidence from the Chinese electronics industry," Information \& Management, vol. 48, no. 2-3, pp. 79-87, 2011.

[119] S. Madon, "Computer-based information systems for decentralized rural development administration: a case study in India," Journal of Information Technology, vol. 7, pp. 20-29, 1992.

[120] C. Urquhart, S. Liyanage, and M. M. O. Kah, "ICTs and poverty reduction: A social capital and knowledge perspective," Journal of Information Technology, vol. 23, no. 3, pp. 203-213, 2008.

[121] V. Venkatesh, T. A. Sykes, and S. Venkatraman, "Understanding e-Government portal use in rural India: Role of demographic and personality characteristics," Information Systems Journal, vol. 24, no. 3, pp. 249-269, 2014.

[122] D. H. Brown and S. Thompson, "Priorities, policies and practice of e-government in a developing country context: ICT infrastructure and diffusion in Jamaica," European Journal of Information Systems, vol. 20, no. June 2009, pp. 329-342, 2011. 
[123] U. Yavas, M. Luqmani, and Z. A. Quraeshi, "Facilitating the adoption of information technology in a developing country," Information \& Management, vol. 23, no. 2, pp. 75-82, 1992.

[124] R. L. R. Ibrahim, "Computer usage in developing countries: Case study Kuwait," Information and Management, vol. 8, no. 2, pp. 103$112,1985$.

[125] C. Okoli, V. W. a Mbarika, and S. McCoy, "The effects of infrastructure and policy on e-business in Latin America and Sub-Saharan Africa," European Journal of Information Systems, vol. 19, no. 1, pp. 5-20, 2010.

[126] V. Venkatesh and T. A. Sykes, "Digital Divide Initiative Success in Developing Countries: A Longitudinal Field Study in a Village in India," Information Systems Research, vol. 24, no. 2, pp. 239-260, 2013.

[127] C. Saunders, "Information Systems in Developing Countries," MIS Quarterly, vol. 31, no. 2, pp. iii-vi, 2007.

[128] A. Chaudhuri, "ICT for development: Solutions seeking problems," Journal of Information Technology, vol. 27, no. 4, pp. 326-338, 2012.

[129] J. Ferguson, M. Soekijad, M. Huysman, and E. Vaast, "Blogging for ICTD: Reflecting and engaging with peers to build development discourse," Information Systems Journal, vol. 23, no. 4, pp. 307-328, 2013.

[130] S. Kurnia, R. J. Karnali, and M. M. Rahim, "A qualitative study of business-to-business electronic commerce adoption within the Indonesian grocery industry: A multi-theory perspective," Information and Management, vol. 52, no. 4, pp. 518-536, 2015.

[131] V. L. Perez, "Factors Challenging Information Technology Applications in Developing Countries," Information \& Management, vol. 3, pp. 141-147, 1980.

[132] G. Walsham, "Decentralization of IS in developing countries: power to the people," Journal of Information Technology, vol. 8, pp. 74 81, 1993.

[133] J. M. Njihia and Y. Merali, “The Broader Context for ICTD Projects: A Morphogenetic Analysis," MIS Quarterly, vol. 37, no. 3, pp. $881-905,2013$.

[134] J. B. Pick and R. Azari, "A Global Model of Technological Utilization Based on Governmental, Business-Investment, Social, and Economic Factors," Journal of Management Information Systems, vol. 28, no. 1, pp. 49-84, 2011.

[135] C. K. Han and B. Render, "Information systems for development management in developing countries," Information \& Management, vol. 17, no. 2, pp. 95-103, 1989.

[136] M. Anandarajan, M. Igbaria, and U. P. Anakwe, "Technology acceptance in the banking industry: A perspective from a less developed country," Information Technology \& People, vol. 13, no. 4, p. 298-312 ST-Technology acceptance in the banking, 2000.

[137] L. Silva and E. Figueroa B., "Institutional intervention and the expansion of ICTs in Latin America: The case of Chile," Information Technology People, vol. 15, no. 1, pp. 8-25, 2002.

[138] Z. A. Damtew and M. Aanestad, "Benefits of Local Knowledge in Shaping Standards," Scandinavian Journal of Information Systems, vol. 24, no. 2, 2012.

[139] K. D. Wowak, C. M. Angst, I. Adjerid, and J. C. Guzman, "A Tutorial on Empirical ICTD Research in Developing Countries: Processes, Challenges, and Lessons," Communication of the Association for Information Systems, vol. 38, no. Article 21, pp. 353-374, 2016.

[140] J. Tan and S. Ludwig, "Regional Adoption of Business-to-Business Electronic Commerce in China," International Journal of Electronic Commerce, vol. 20, no. 3, pp. 408-439, 2016.

[141] J. M. Alcaraz, M. Domènech, and F. Tirado, "EHR software, multinational corporations and emerging China: Exploring the role of information through a postcolonial lens," Information and Organization, vol. 22, no. 2, pp. 106-124, 2012.

[142] S. A. Mengiste and M. Aanestad, "Understanding the dynamics of learning across social worlds: A case study from implementing IS in the Ethiopian public health care system," Information and Organization, vol. 23, no. 4, pp. 233-257, 2013.

[143] R. L. La Rovere, "Diffusion of information technologies and changes in the telecommunications sector: The case of Brazilian small- and medium-sized enterprises," Information Technology \& People, vol. 11, no. 3, pp. 194-206, 1998.

[144] R. Montealegre, "Waves of change in adopting the Internet: Lessons from four Latin American Countries," Information Technology \& People, vol. 11, no. 3, pp. 235-260, 1998.

[145] M. O. S. Mahdi and P. Dawson, "The introduction of information technology in the commercial banking sector of developing countries: voices from Sudan," Information Technology \& People, vol. 20, no. 2, pp. 184-204, 2007.

[146] K. C. Lun, "Telemedicine in the Asia Pacific," International Journal of Medical Informatics, vol. 61, no. 2-3, pp. 85-86, 2001.

[147] M. Graven, P. Allen, I. Smith, and N. E. MacDonald, "Decline in mortality with the Belize Integrated Patient-Centred Country Wide Health Information System (BHIS) with Embedded Program Management," International Journal of Medical Informatics, vol. 82, no. 10, pp. 954-963, 2013.

[148] A. K. Singh, M. Kohli, E. Trell, O. Wigertz, and S. Kohli, "Bhorugram (India): revisited. A 4 year follow-up of a computer-based information system for distributed MCH services," International Journal of Medical Informatics, vol. 44, no. 2, pp. 117-125, 1997.

[149] S. Sahay, J. Sæbø, and J. Braa, "Scaling of HIS in a global context: Same, same, but different," Information and Organization, vol. 23, no. 4, pp. 294-323, 2013.

[150] P. Esmaeilzadeh, M. Sambasivan, N. Kumar, and H. Nezakati, "Adoption of clinical decision support systems in a developing country: Antecedents and outcomes of physician's threat to perceived professional autonomy," International Journal of Medical Informatics, vol. 84, no. 8, pp. 548-560, 2015.

[151] M. Kirlidog, "Information technology transfer to a developing country," Information Technology \& People, vol. 9, no. 3, pp. 55-84, 1996. 
[152] A. A. Adekoya, E. Eyob, F. M. Ikem, E. O. Omojokun, A. M. Quaye, and A. O. Bada, "Dynamics of information technology (IT) successful implementation in development countries: A Nigerian case study," Journal of Computer Information Systems, vol. 45, no. 3, pp. 107-112, 2005.

[153] D. J. Mccubbrey, "The EDI project in Slovenia : a case study and model for developing countries," vol. 8, no. 2, pp. 6-16, 1995.

[154] F. J. Mata and W. L. Fuerst, "Information systems management issues in Central America: a multinational and comparative study," The Journal of Strategic Information Systems, vol. 6, no. 3, pp. 173-202, 1997.

[155] I. Karikari, J. Stillwell, and S. Carver, "The application of GIS in the lands sector of a developing country: Challenges facing land administrators in Ghana," International Journal of Geographical Information Science, vol. 19, no. 3, pp. 343-362, 2005.

[156] V. A. Trần, H. L. Seldon, H. D. Chu, and K. P. Nguyễn, "Electronic healthcare communications in Vietnam in 2004," International Journal of Medical Informatics, vol. 75, no. 10-11, pp. 764-770, 2006.

[157] K. Alshare, M. Al-Dwairi, and I. Akour, "Student-instructor perception of computer technologies in developing countries: The case of Jordan," Journal of Computer Information Systems, vol. 43, no. October, pp. 115-122, 2003.

[158] S. K. Puri, S. Sahay, and J. Lewis, "Building participatory HIS networks: A case study from Kerala, India," Information and Organization, vol. 19, no. 2, pp. 63-83, 2009.

[159] R. Kuriyan, K. Kitner, and J. Watkins, "ICTs, development and trust: an overview," Information Technology \& People, vol. 23, no. 3, pp. 216-221, 2010.

[160] K. Masters, “Access to and use of the Internet by South African general practitioners," International Journal of Medical Informatics, vol. 77, no. 11, pp. 778-786, 2008

[161] R. Gomez and E. Gould, "The 'cool factor' of public access to ICT,” Information Technology \& People, vol. 23, no. 3, pp. 247-264, 2010.

[162] A. I. Matheson, J. G. Baseman, S. H. Wagner, G. E. O’Malley, N. H. Puttkammer, E. Emmanuel, G. Zamor, R. Frédéric, N. R. Coq, and W. B. Lober, "Implementation and expansion of an electronic medical record for HIV care and treatment in Haiti: An assessment of system use and the impact of large-scale disruptions," International Journal of Medical Informatics, vol. 81, no. 4, pp. 244-256, 2012.

[163] A. Maunder, G. Marsden, and R. Harper, "Making the link - Providing mobile media for novice communities in the developing world," International Journal of Human Computer Studies, vol. 69, no. 10, pp. 647-657, 2011.

[164] L. Hanmer, "Criteria for the evaluation of district health information systems.," International journal of medical informatics, vol. 56, no. 1-3, pp. 161-8, 1999.

[165] F. M. E. Uzoka and T. Ndzinge, "Empirical analysis of biometric technology adoption and acceptance in Botswana," Journal of Systems and Software, vol. 82, no. 9, pp. 1550-1564, 2009.

[166] M. Kahouei, J. M. Zadeh, and P. S. Roghani, "The evaluation of the compatibility of electronic patient record (EPR) system with nurses' management needs in a developing country," International Journal of Medical Informatics, vol. 84, no. 4, pp. 263-270, 2015.

[167] A. S. Kanter, J. Negin, B. Olayo, F. Bukachi, E. Johnson, and S. E. Sachs, "Millennium Global Village-Net: Bringing together Millennium Villages throughout sub-Saharan Africa," International Journal of Medical Informatics, vol. 78, no. 12, pp. 802-807, 2009.

[168] N. Hayes and C. Westrup, "Context and the processes of ICT for development," Information and Organization, vol. 22, no. 1, pp. 23-36, 2012.

[169] A. Dutta, "The Physical Infrastructure for Electronic Commerce in Developing Nations: Historical Trends and the Impact of Privatization," International Journal of Electronic Commerce, vol. 2, no. 1, pp. 61-83, 1997.

[170] E. Klecun, "Bringing lost sheep into the fold: questioning the discourse of the digital divide," Information Technology \& People, vol. 21, no. 3, pp. 267-282, 2008.

[171] M. S. Adam and C. Urquhart, "No man is an island: Social and human capital in IT capacity building in the Maldives," Information and Organization, vol. 19, no. 1, pp. 1-21, 2009.

[172] B. Dey, D. Newman, and R. Prendergast, "Analysing appropriation and usability in social and occupational lives," Information Technology \& People, vol. 24, no. 1, pp. 46-63, 2011.

[173] A. D. Andrade and C. Urquhart, "The affordances of actor network theory in ICT for development research," Information Technology \& People, vol. 23, no. 4, pp. 352-374, 2010.

[174] A. Dutta and R. Roy, "The Mechanics of Internet Growth: A Developing-Country Perspective," International Journal of Electronic Commerce, vol. 9, no. 2, pp. 143-165, 2004.

[175] L. H. Iwaya, M. A. L. Gomes, M. A. Simplício, T. C. M. B. Carvalho, C. K. Dominicini, R. R. M. Sakuragui, M. S. Rebelo, M. A. Gutierrez, M. Näslund, and P. Håkansson, "Mobile health in emerging countries: A survey of research initiatives in Brazil," International Journal of Medical Informatics, vol. 82, no. 5, pp. 283-298, 2013.

[176] M. C. Were, C. Shen, M. Bwana, N. Emenyonu, N. Musinguzi, F. Nkuyahaga, A. Kembabazi, and W. M. Tierney, "Creation and evaluation of EMR-based paper clinical summaries to support HIV-care in Uganda, Africa," International Journal of Medical Informatics, vol. 79 , no. 2 , pp. 90-96, 2010.

[177] S. F. Noormohammad, B. W. Mamlin, P. G. Biondich, B. McKown, S. N. Kimaiyo, and M. C. Were, "Changing course to make clinical decision support work in an HIV clinic in Kenya," International Journal of Medical Informatics, vol. 79, no. 3, pp. 204-210, 2010.

[178] Y. Y. Yuen, P. H. P. Yeow, N. Lim, and N. Saylani, “Internet banking adoption: Comparing developed and developing countries,” Journal of Computer Information Systems, vol. 51, no. 1, pp. 52-61, 2010.

[179] S. Sahay and G. Walsham, "Implementation of GIS in India: Organizational issues and implications," International Journal of 
Geographical Information Systems, vol. 10, no. 4, pp. 385-404, 1996.

[180] A. Prakash and R. De', “Importance of development context in ICTD projects," Information Technology \& People, vol. 20, no. 3, pp. 262-281, 2007.

[181] M. Alomari, P. Woods, and K. Sandhu, "Predictors for e-government adoption in Jordan," Information Technology \& People, vol. 25, no. 2, pp. 207-234, 2012.

[182] P. Yu, M. de Courten, E. Pan, G. Galea, and J. Pryor, "The development and evaluation of a PDA-based method for public health surveillance data collection in developing countries," International Journal of Medical Informatics, vol. 78, no. 8, pp. 532-542, 2009.

[183] S. Madon, "The Internet and socio- economic development : exploring the interaction,” Information Technology \& People, vol. 13, no. 2, pp. 85-101, 2000.

[184] B. Kijsanayotin, S. Pannarunothai, and S. M. Speedie, "Factors influencing health information technology adoption in Thailand's community health centers: Applying the UTAUT model," International Journal of Medical Informatics, vol. 78, no. 6, pp. 404-416, 2009.

[185] C. Ciborra, "Interpreting e-government and development," Information Technology \& People, vol. 18, no. 3, pp. 260-279, 2005.

[186] B. Gupta, S. Dasgupta, and A. Gupta, "Adoption of ICT in a government organization in a developing country: An empirical study," Journal of Strategic Information Systems, vol. 17, no. 2, pp. 140-154, 2008.

[187] A. Molla and P. S. Licker, "Perceived E-Readiness Factors in E-Commerce Adoption: An Empirical Investigation in a Developing Country," International Journal of Electronic Commerce, vol. 10, no. 1, pp. 83-110, 2005.

[188] S. Wyche, N. Simiyu, and M. E. Othieno, "Mobile Phones as Amplifiers of Social Inequality among Rural Kenyan Women," ACM Transactions on Computer-Human Interaction, vol. 23, no. 3, pp. 1-19, 2016.

[189] V. Venkatesh, A. Rai, T. A. Sykes, and R. Aljafari, "Combating Infant Mortality in Rural India: Evidence from a field study of eHealth Kiosk Implementations,” MIS Quarterly, vol. 40, no. 2, pp. 353-380, 2016.

[190] R. Heeks, "Deriving an ICTD research agenda: A commentary on 'Information and communication technologies for development (ICTD): solutions seeking problems?," Journal of Information Technology, vol. 27, no. 4, pp. 339-341, 2012.

[191] C. I. C. Lin, F.-Y. Kuo, and M. D. Myers, "Extending ICTD Studies: The Value of Critical Research,” MIS Quarterly, vol. 39, no. 3, pp. 697-712, 2015.

[192] R. Jayasuriya, "Stages of growth in end-user computing: applications in the health sector of developing countries in Asia-Pacific," Journal of Information Technology, vol. 8, pp. 151-159, 1993. 